Article

\title{
Physicochemical Properties of Gac (Momordica cochinchinensis (Lour.) Spreng) Seeds and Their Oil Extracted by Supercritical Carbon Dioxide and Soxhlet Methods
}

\author{
Anh V. Le ${ }^{1,2, *(\mathbb{D})}$, Sophie E. Parks ${ }^{1,3}$, Minh H. Nguyen ${ }^{1,4}$ (D) and Paul D. Roach ${ }^{1}$ \\ 1 School of Environmental and Life Sciences, University of Newcastle, Ourimbah NSW 2258, Australia; \\ sophie.parks@dpi.nsw.gov.au (S.E.P.); Minh.Nguyen@newcastle.edu.au (M.H.N.); \\ Paul.Roach@newcastle.edu.au (P.D.R.) \\ 2 Faculty of Bio-Food Technology and Environment, University of Technology (HUTECH), \\ Ho Chi Minh City 700000, Vietnam \\ 3 Central Coast Primary Industries Centre, NSW Department of Primary Industries, \\ Ourimbah NSW 2258, Australia \\ 4 School of Science and Health, Western Sydney University, Penrith NSW 2751, Australia \\ * Correspondence: vananh.le@uon.edu.au
}

Received: 25 September 2018; Accepted: 9 October 2018; Published: 11 October 2018

\begin{abstract}
Gac seeds are high in oil, but there are few studies on its extraction and characteristics. This study aimed to characterise Gac seeds and investigate the physicochemical properties of Gac seed oil extracted with supercritical carbon dioxide $\left(\mathrm{SC}-\mathrm{CO}_{2}\right)$ and hexane (Soxhlet). The Gac seed kernel accounted for $66.4 \pm 2.7 \%$ of the seed weight, and $53.02 \pm 1.27 \%$ of it was oil. The SC- $\mathrm{CO}_{2}$ oil had a higher quality than the Soxhlet oil for important criteria, such as peroxide $\left(0.12 \pm 0.02\right.$ vs. $1.80 \pm 0.01 \mathrm{meq} \mathrm{O}_{2} / \mathrm{kg}$ oil $)$, free fatty acid $(1.74 \pm 0.12$ vs. $2.47 \pm 0.09 \mathrm{mg} \mathrm{KOH} / \mathrm{g}$ oil) and unsaponifiable matter $(33.2 \pm 1.5$ vs. $52.6 \pm 2.4 \mathrm{~g} / \mathrm{kg})$ values, respectively. It also had a better colour (light yellow vs. dark greenish brown) and a higher antioxidant capacity measured with the DPPH (52.69 \pm 0.06 vs. $42.98 \pm 0.02 \mu \mathrm{mol}$ Trolox equivalent/g oil) and ABTS (2.10 \pm 0.12 vs. $1.52 \pm 0.06 \mu \mathrm{mol}$ Trolox equivalent/g oil) assays. However, a higher yield $(53.02 \pm 1.27$ vs. $34.1 \pm 0.8 \%)$ was obtained for the Soxhlet oil. Unless refined, the oils would not be edible due to their high unsaponifiable matter, but the $\mathrm{SC}-\mathrm{CO}_{2}$ oil would need less refining. Alternatively, the high unsaponifiable matter in the oil, especially in the Soxhlet oil, may make it useful for medicinal purposes.
\end{abstract}

Keywords: Momordica cochinchinensis; Gac seeds; oil; characteristics; supercritical carbon dioxide; Soxhlet

\section{Introduction}

Gac (Momordica cochinchinensis (Lour.) Spreng), also known as red melon, baby jackfruit, spiny bitter gourd, sweet gourd or cochinchin gourd, is found throughout the Southeast Asian region from South China to Northeastern Australia, including Thailand, Laos, Myanmar, Cambodia and Vietnam [1]. The most important part of the fruit is the red flesh surrounding the seeds, the aril, which is used as a colorant in rice or as a material for further processing into functional food ingredients and supplements since the Gac aril is well known by its high content of lycopene and $\beta$-carotene [2]. In factories, after the aril is recovered, the remaining seeds, pulp and peel are mostly considered waste and have very little use [3]. However, in the traditional medicine of countries like China and Vietnam, Gac seeds have been used as a treatment for a range of diseases such as fluxes, liver and spleen disorders, haemorrhoids, wounds, bruises, swelling and pus [4,5]. 
Several studies have demonstrated that the kernel of Gac seeds contains a high proportion of oil, which ranges from $35 \%$ [6] to $53 \% \mathrm{w} / \mathrm{w}$ [7]. Two common methods used for recovering oil from seeds are expeller pressing and conventional solvent extraction, mainly using hexane. The pressing process yields extracts of high quality; however, in most cases, the yield is low and the oil can be subject to thermal degradation. The latter achieves almost complete recovery of the oil as determined using the closed circuit continuous reflux system of the Soxhlet apparatus. However, the solvent extraction method can cause unacceptable solvent contamination, which can be harmful to human health and/or the environment, and thus, the use of oil produced in this way may be restricted in the food, cosmetic and pharmaceutical industries for safety reasons [8].

Many reports have shown that seed oils can be extracted using supercritical carbon dioxide $\left(\mathrm{SC}-\mathrm{CO}_{2}\right)$, which is environmentally friendly and organic solvent-free. This technique has been employed to extract oil from many kinds of seeds with oil yields that are comparable to the conventional solvent extraction methods [9,10]. Although the optimal conditions for extracting Gac seed oil using SC- $\mathrm{CO}_{2}$ have been reported recently [11], to our knowledge, there are no reports comparing the physicochemical characteristics of Gac seed oil extracted with SC- $\mathrm{CO}_{2}$ with Gac seed oil extracted using the conventional hexane extraction method with the Soxhlet apparatus.

Therefore, the aim of this study was to characterise the oil extracted from Gac seed kernels using a SC- $\mathrm{CO}_{2}$ system and compare it to oil extracted using the conventional solvent extraction method with hexane and the Soxhlet apparatus (Soxhlet). The extracted oils were compared in terms of extraction yield and physiochemical indices, including their antioxidant capacity.

\section{Materials and Methods}

\subsection{Materials}

\subsubsection{Chemicals}

Organic solvents including hexane, methanol and ethanol were obtained from Merck Pty Ltd. (Kilsyth, VIC, Australia). 2,2'-azinobis-(3-ethylbenzothiozoline-6-sulfonic) acid (ABTS), 2,2'-diphenyl-1-picrylhydrazyl (DPPH) and Trolox were purchased from Sigma-Aldrich Pty Ltd. (Castle Hill, NSW, Australia). Carbon dioxide (99.9\%) was purchased from Coregas Pty. Ltd. (Mayfield, NSW, Australia). All chemicals were of analytical grade.

\subsubsection{Gac Seed Kernels}

Twenty kilograms of seeds were separated from fresh Gac fruits collected in Ho Chi Minh (HCM) city, Vietnam (latitude: 10.757410; longitude: 106.673439). The average weight of the fresh Gac seeds was determined immediately after they were separated from the fruit arils. Three samples of 200 fresh seeds were randomly taken from the well-mixed $20-\mathrm{kg}$ lot of seeds and weighed using an analytical balance $(\varepsilon=0.0001 \mathrm{~g})$.

For prolonged preservation and to facilitate the removal of their shells, the seeds were vacuum dried at $40^{\circ} \mathrm{C}$ for $24 \mathrm{~h}$ to reduce their moisture and to increase the breakability of their shells. The dried seeds were then de-shelled manually using a knife. The average weight of the dried whole seeds and the dried de-shelled kernels was determined before and after de-shelling. Three samples of 300 dried seeds were taken randomly from the well-mixed dried seeds and weighed using an analytical balance $(\varepsilon=0.0001 \mathrm{~g})$. The seeds in the three samples were then de-shelled, and the resulting three samples of kernels were weighed. Equation (1) was used to calculate what percentage the weight of the kernels was in terms of the weight of the dried seeds before they were deshelled. The results were expressed as the mean value \pm the standard deviation.

$$
\text { Kernel }(\%)=\frac{\text { mass of kernels }}{\text { mass of whole seeds }} \times 100
$$


The dried kernels were packaged in vacuum-sealed aluminium bags and stored at $4{ }^{\circ} \mathrm{C}$ before further investigation.

\subsection{Proximate Analysis of the Gac Seed Kernels}

The moisture, protein and fat contents of the Gac seed kernels were determined in triplicate samples using the official methods and recommended practices of the American Oil Chemists' Society (AOCS) [12]. Moisture was measured using the AOCS Ab 2-49 method and using a MOC63u moisture analyser (Shimadzu Corp., Kyoto, Japan) at $160{ }^{\circ} \mathrm{C}$; crude protein was measured using the AOCS Ba 4d-90 method and a Kjeldahl apparatus; and oil content was measured using the AOCS Am 2-93 method using a Soxhlet apparatus.

\subsection{Preparation of Gac Seed Kernel Powder for Oil Extraction}

Before conducting extractions, the Gac seed kernels were ground into a powder of less than a 500- $\mu \mathrm{m}$ particle size, using the $100 \mathrm{~g}$ ST-02A Mulry Disintegrator (Taiwan Machinary, Sydney, NSW, Australia). The powder was then dried in a Dynavac FD3 freeze dryer (Dynapumps, Seven Hills, NSW, Australia) for $48 \mathrm{~h}$ at $-45^{\circ} \mathrm{C}$ under vacuum at a pressure loading of $10^{-2}$ mbar $(1 \mathrm{~Pa})$. The remaining moisture of the freeze-dried powder was $1.21 \pm 0.02 \%$, as measured at $160{ }^{\circ} \mathrm{C}$ using a Shimadzu MOC63u moisture analyser (Shimadzu Corp., Kyoto, Japan).

\subsection{Methods for the Extraction of Gac Seed Oil}

\subsubsection{SC- $\mathrm{CO}_{2}$ Extraction}

The extraction of Gac seed oil with $\mathrm{SC}-\mathrm{CO}_{2}$ was performed using a laboratory-scale supercritical fluid extraction system (Teledyne Isco, Lincoln, NE, USA), which consisted of an SFX 2-10 extractor and two 260D syringe pumps. The extractor was a $10-\mathrm{mL}$ cartridge through which $\mathrm{SC}-\mathrm{CO}_{2}$ flowed downwards. The operation parameters of the system ranged between 10 and 7500 psi for pressure, ambient, $150{ }^{\circ} \mathrm{C}$ for temperature and 0.001 and $107 \mathrm{~mL} / \mathrm{min}$ for $\mathrm{CO}_{2}$ flow rate. Based on the results from optimisation investigations on the Gac seed oil yield [11], the extraction conditions were set at a temperature of $73^{\circ} \mathrm{C}$, a $\mathrm{CO}_{2}$ pressure of $5900 \mathrm{psi}$ and a $\mathrm{CO}_{2}$ flow rate of $1.5 \mathrm{~mL} / \mathrm{min}$.

For each extraction $(n=3), 4 \mathrm{~g}$ of $\mathrm{Gac}$ seed kernel powder were added to the $10-\mathrm{mL}$ extraction cartridge, which was then placed in the extraction vessel. The oil- $\mathrm{CO}_{2}$ mixture was passed through the coaxially-heated adjustable restrictor set at $70{ }^{\circ} \mathrm{C}$ to evaporate the $\mathrm{CO}_{2}$, and the oil was collected in a pre-weighed glass tube $(\approx 10 \mathrm{~min})$. The tube was then weighted to calculate the oil yield, and the oil was transferred into dark sealed vials and stored at $-20^{\circ} \mathrm{C}$ before further analysis.

\subsubsection{Soxhlet Extraction}

For quantitative and qualitative comparisons with the $\mathrm{SC}-\mathrm{CO}_{2}$ extracted oil, oil was extracted with the conventional Soxhlet extraction method as described by Da Porto et al. [13] with some modifications. Briefly, for each extraction $(\mathrm{n}=3), 7 \mathrm{~g}$ of Gac seed kernel powder were added to a cellulose thimble, plugged with glass wool and put into a Soxhlet extractor. Approximately $250 \mathrm{~mL}$ n-hexane were added into a pre-weighed boiling flask, which was fitted to the extractor and condenser. The solvent flow rate was recorded as $14 \mathrm{~min} /$ cycle, and the extraction process was terminated after $8 \mathrm{~h}$. After extraction, the n-hexane was removed under reduced pressure at $50{ }^{\circ} \mathrm{C}$ using a Buchi Rotavapor B480 evaporator (Buchi Australia, Noble Park, VIC, Australia). The remaining traces of hexane were then removed using a flow of compressed nitrogen blowing on the surface of the oil until the weight of the flask was constant $(\approx 3 \mathrm{~min})$. The weight of the flask containing the oil was then recorded to calculate the oil yield, and the oil was transferred to dark sealed vials and stored at $-20^{\circ} \mathrm{C}$ before analysis. 


\subsection{Oil Yield Calculation}

The 3 oil samples extracted by each method were precisely weighed using a 2-digit digital balance, which had also been used for weighing the initial Gac seed kernel powder samples. The oil yield was expressed in terms of mass percentage as formulated in Equation (2).

$$
\text { Oil yield }(\%)=\frac{\text { mass of oil extracted }(g)}{\text { mass of sample }(g)} \times 100 \%
$$

\subsection{Methods for Characterisation of Oils}

\subsubsection{Determination of Physicochemical Indices}

Oils extracted from the Gac seed kernel powder using $\mathrm{SC}-\mathrm{CO}_{2}$ or and the Soxhlet method with hexane were subjected to physical and chemical analyses following the official AOCS methods [12] as follows: specific gravity: AOCS Cc 10a-25; refractive index: AOCS Cc 7-25; slip melting point: AOCS Cc 3-25; free fatty acids: AOCS Ca 5a-40; peroxide value: AOCS Cd 8-53; saponification value: AOCS Cd 3-35; unsaponifiable matter: AOCS Ca 6a-40; iodine value: AOCS Cd 1-25; insoluble impurities: AOCS Ca 3-46; moisture and volatile matter: AOCS Ca 2c-25.

\subsubsection{Colour Measurement}

The colour of Gac seed oils was conducted according to $\mathrm{Xu}$ [14] with several modifications, using a chroma meter (Minolta CR-400, Minolta Camera Co., Ltd, Osaka, Japan). Oil samples were placed in standard disposable cuvettes $(1 \mathrm{~cm}$ optical path), and a white calibration plate was used as the background (for illuminants D65, $Y=93.5, x=0.3140, y=0.3318$ ). Before the measurements, the instrument was calibrated with deionized water. Measurements were performed on liquid oil samples at ambient temperature $\left(27^{\circ} \mathrm{C}\right)$. For each sample, three points along the height of the cuvette were measured, and the colour result of each sample was the average of the three measurements. The absolute measurements were displayed in $\mathrm{L}^{*}, \mathrm{a}^{*}$ and $\mathrm{b}^{*}$ co-ordinates as defined by CIE (Commission Internationale de $l^{\prime}$ Eclairage). The $L^{*}$ value represents the lightness-darkness dimension; the $a^{*}$ value represents the red-green dimension; and the $b^{*}$ value represents the yellow-blue dimension.

\subsubsection{Determination of Antioxidant Activity}

The seed oils obtained by the two techniques were subjected to analysis of their antioxidant activity using the DPPH and the ABTS radical-scavenging assays. All data were averages ( \pm standard deviations) of triplicate determinations of three independent oil samples for each extraction method.

\section{- DPPH radical-scavenging assay}

The scavenging activity of Gac seed oils towards DPPH radicals was determined by the method of Tan et al. [15] with some modifications; the main modification was that ethyl acetate was used as the solvent instead of methanol to ensure the oil samples were well dissolved. Each of the oil samples $(0.20 \mathrm{~g})$ was diluted in ethyl acetate $(10 \mathrm{~mL})$. A stock solution of $0.6 \mathrm{mmol} / \mathrm{L} \mathrm{DPPH}$ in ethyl acetate was prepared and kept at $4{ }^{\circ} \mathrm{C}$ to be used within a week. Fresh working solution was prepared for each assay by mixing $8 \mathrm{~mL}$ of stock solution with $42 \mathrm{~mL}$ of ethyl acetate to obtain an absorbance of $1.1 \pm 0.02$ units at $515 \mathrm{~nm}$. The reaction was initiated by mixing the diluted oil sample $(0.15 \mathrm{~mL})$ with the DPPH working solution $\left(3.85 \mathrm{~mL}\right.$ ). Absorbance was measured at $\lambda_{\max }$ of $515 \mathrm{~nm}$ in a Cary $60 \mathrm{UV}$-Vis spectrophotometer (Agilent Technologies, Mulgrave, VIC, Australia) after $6 \mathrm{~h}$ storage in the dark (experimentally determined as the steady state of reaction). Trolox was used as a standard, and the anti-oxidant activity was expressed as $\mu \mathrm{mol}$ trolox equivalents (TE) per $\mathrm{g}$ of oil ( $\mu \mathrm{mol} \mathrm{TE} / \mathrm{g}$ ). 


\section{- ABTS assay}

The ABTS assay was conducted according to Christodouleas et al. [16] with several modifications to ensure it worked with the oil samples. The ABTS was dissolved in pure methanol, and potassium persulfate $\left(\mathrm{K}_{2} \mathrm{~S}_{2} \mathrm{O}_{8}\right)$ was dissolved in $50 \%$ methanol to a final concentration of $5.92 \mathrm{mM}$ and $2.08 \mathrm{mM}$, respectively. These two solutions were mixed at a $1: 1(\mathrm{v} / \mathrm{v})$ ratio, and the mixture was allowed to stand in the dark at ambient temperature for $24 \mathrm{~h}$ in order to produce the ABTS free radical (ABTS ${ }^{\bullet+}$ ). Then, the solution was diluted with ethanol at a ratio of 1:15 (v/v) solution: ethanol and left in the dark for another $3 \mathrm{~h}$ to obtain an absorbance of $1.00 \pm 0.02$ units at $734 \mathrm{~nm}$. Each oil sample $(0.2 \mathrm{~g})$ was dissolved in $10 \mathrm{~mL}$ of dichloromethane. The reaction was initiated by mixing the dissolved oil sample $(0.15 \mathrm{~mL})$ with the diluted ABTS ${ }^{\bullet+}$ solution $(2.85 \mathrm{~mL})$ left to stand in the dark for $2 \mathrm{~h}$. The absorbance was then measured at the $\lambda_{\max }$ of $734 \mathrm{~nm}$ in a Cary $60 \mathrm{UV}$-Vis spectrophotometer (Agilent Technologies, Mulgrave, VIC, Australia). Trolox was used as a standard, and the antioxidant activity was expressed as $\mu \mathrm{mol}$ trolox equivalents (TE) per $\mathrm{g}$ of oil ( $\mu \mathrm{mol} \mathrm{TE} / \mathrm{g})$.

\subsection{Statistical Analyses}

Oil extractions and other measurements were performed in triplicate, and the results were expressed as the means \pm SD. Student's $t$-test, conducted using Microsoft Excel 2010, was used to compare the difference between the mean values for the $\mathrm{SC}-\mathrm{CO}_{2}$ and Soxhlet oils and statistical significance was taken to be at $p<0.05$.

\section{Results and Discussion}

\subsection{Characteristics of Gac Seeds}

The characteristics of the Gac seeds and their macro constituents are shown in Table 1. The results of the weight analysis of the Gac seeds revealed that the weight of the fresh and dried Gac seeds was quite consistent, with the variation being within $4 \%$ of the mean seed weight. The average weight of these fresh seeds was similar to the weight reported by Ishida et al. [17]. This is likely because these seeds were sourced from the same country (Vietnam) and were possibly from the same variety. During drying, the seeds lost $38 \%$ of their weight (Table 1). After de-shelling, the dried kernels were $34 \%$ lower in weight than the whole dried seeds, meaning that $66 \%$ of the dried seed weight was in the kernel and $34 \%$ in the shell. This is the first report of the Gac kernel to shell ratio, and the shell weight was found to be much higher than for other dried oil seeds. For example, the hull ranged from 9-15\% for Mucuna seeds [18] and from 20-30\% for sunflower seeds [19].

Table 1. Proximate analysis of dried Gac seeds.

\begin{tabular}{ccc}
\hline Characteristics & Component & Mean \pm SD \\
\hline Average seed weight $(\mathrm{g})^{\dagger}$ & Fresh seeds & $5.07 \pm 0.19^{\mathrm{a}}$ \\
Average seed weight $(\mathrm{g})^{\dagger}$ & Dried seeds & $3.15 \pm 0.12^{\mathrm{b}}$ \\
Average kernel weight $(\mathrm{g})^{\dagger}$ & Dried kernels & $2.09 \pm 0.33^{\mathrm{c}}$ \\
Moisture (\%) Moisture Analyser $\ddagger$ & Dried kernels & $3.34 \pm 0.10^{\mathrm{z}}$ \\
Moisture (\%) AOCS: Ab 2-49 $\ddagger$ & Dried kernels & $3.47 \pm 0.11^{\mathrm{z}}$ \\
Crude protein $(\%)^{\ddagger}$ & Dried kernels & $17.33 \pm 0.47^{\mathrm{y}}$ \\
Oil content $(\%)^{\ddagger}$ & Dried kernels & $53.02 \pm 1.27^{\mathrm{x}}$
\end{tabular}

\footnotetext{
+ The mean \pm SD (standard deviation) weights for 3 random samples of 200 fresh seeds or 300 dried seeds or kernels, and values not sharing the same superscript letter $\left(\mathrm{a}, \mathrm{b},{ }^{\mathrm{c}}\right)$ are significantly different $(p<0.05)$. ${ }^{\ddagger}$ The mean \pm SD percentage for 3 independent sample determinations, and values not sharing the same superscript letter $(\mathrm{x}, \mathrm{y}, \mathrm{z})$ are significantly different $(p<0.05)$.
}

Due to the high relative weight of the Gac seed shell, the shell should be removed before oil extraction. Besides reducing the volume of material to be extracted, removing the seed shell is likely to improve the quality of the oil in terms of colour and purity [20]. However, the shell represents 
a substantial component of the Gac seeds, and therefore, studies on the constituents in the shell should be done to determine whether this part of the seeds can be utilised, because otherwise, it still represents a considerable waste burden.

The seed weight may be important for the industrial processing of Gac seeds as observed by Saiedirad et al. [21] for seeds in general in that not all seeds required the same grinding conditions and that variability in weight can affect the grinding time and the uniformity of the resulting powder.

Drying at $40{ }^{\circ} \mathrm{C}$ for $24 \mathrm{~h}$ resulted in the moisture content of the Gac seed kernels, measured using two methods (Table 1), being much lower than the safe moisture upper limit of $6 \%$ suggested by Brooker et al. [22] for oilseed storage. Therefore, the vacuum drying conditions of $40{ }^{\circ} \mathrm{C}$ for $24 \mathrm{~h}$ used in this study can be applied to sufficiently dry Gac seeds so that they can be safely stored for a longer time without spoilage than the fresh seeds. However, from the energy-saving perspective, studies on the optimisation of the drying methods and the drying conditions used to dry Gac seeds are needed.

The moisture content of the dried kernels was not significantly different $(p=0.2)$ between the two methods used (Table 1), and therefore, the infrared moisture determination balance can be used instead of the more time-consuming AOCS method for analysing the moisture content of Gac seeds.

The protein content of the Gac seed kernels (Table 1) was lower than for other common oilseeds (23.1-33.0\%) such as soybeans, cowpeas, pigeon peas, melon, pumpkin and gourd seeds [23]. The crude protein constituent of an oilseed can also affect the oil extraction process. In oilseeds, proteins form a membrane around the lipid bodies, which needs to be broken down before the oil is able to be extracted [24,25]. Therefore, the low content of protein in Gac seed kernels can be an advantage for the extraction of their oil. However, the known presence of trypsin inhibitor proteins in Gac seeds [26], which can have anti-nutritive effects [27], might hinder the possibility of using Gac seed protein in human food or animal feed.

The oil content of the Gac seed kernels (Table 1) was similar to that reported previously (52.7\%) for Gac seed kernels [7] and comparable to the values for other oil-rich seeds like peanuts (45-52\%) [28], sunflower kernels (45-55\%) [29] and sesame seeds (30-50\%) [30] and higher than for linseeds (33.3\%), soybeans (18.4\%) and palm kernels (44.6\%) [31]. Therefore, Gac seed kernels are one of the richest sources of oil, which should make it easy to recover for analysis and potential use, such as edible oil, medicinal or cosmetic ointment.

\subsection{Oil Yield}

Table 2 shows the oil yield obtained from the two studied extraction methods. On a mass per mass basis $(\%, \mathrm{~m} / \mathrm{m})$, the Soxhlet method with hexane was more effective at extracting oil from the Gac seed kernels; a 36\% higher oil yield was obtained for the Soxhlet method than for the SC-CO 2 method. This is likely because hexane is more lipophilic than $\mathrm{CO}_{2}$, and based on the chemical analysis (Table 2), it was able to extract more triglycerides and other non-polar compounds from the kernels. The oil extracted with hexane had a higher unsaponifiable matter component and a lower saponifiable matter component than its SC-CO $\mathrm{CO}_{2}$ counterpart (Table 2), but this did not explain much of the difference in the amount of oil extracted. Thus, the extraction method can affect the yield of oil from Gac seeds.

For other types of seeds, the oil yield also tends to be higher when the oil is extracted using hexane than when the SC- $\mathrm{CO}_{2}$ method is used. However, the differences are not usually as great as was observed for the Gac seeds in the present study; Zhao et al. [32] reported 24.1\% and 27.2\% oil yields for radish seeds when extracted by $\mathrm{SC}-\mathrm{CO}_{2}$ and hexane, respectively, and Molero et al. [33] reported close values of $36.0 \%$ and $38.4 \%$ for oil yields from sunflower seeds and $39.3 \%$ and $40.1 \%$ from grape seeds.

\subsection{Characterisation of the Extracted Oils}

Several characteristics are usually measured to give information about the structure, stability and quality of seed oils. The physicochemical and quality characteristics of the two oils extracted by the SC- $\mathrm{CO}_{2}$ and the Soxhlet methods are shown in Table 2. This is the first time that these characteristics 
have been reported for Gac seed oil. The results revealed that all the measured physical and chemical characteristics were significantly different $(p<0.05)$ between the oils extracted by the two methods.

The specific gravity (or relative density) of the $\mathrm{SC}-\mathrm{CO}_{2}$ oil was higher than for the Soxhlet oil, suggesting that the $\mathrm{SC}-\mathrm{CO}_{2}$ oil contained less long chain saturated fatty acids and/or more unsaturated fatty acids than the Soxhlet oil [31]. This may be due to hexane having a higher lipophilicity than $\mathrm{SC}-\mathrm{CO}_{2}$, and thus, it was more efficient at extracting long chain saturated fatty acids. At the same temperature, the higher the density of an oil is, the shorter the average fatty acid chains it contains [34]. Generally, the density of an oil decreases with the molecular weight of its fatty acids, but its density increases with the degree of unsaturation of the fatty acids [35].

One of the factors that affects an oil's specific gravity, the degree of unsaturation, is measured by the refractive index and the iodine value, which decrease and increase, respectively, with the degree of unsaturation of the fatty acids in the oil [36,37]. Consistent with its higher specific gravity, the refractive index value of the $\mathrm{SC}-\mathrm{CO}_{2}$ oil was lower than that of the Soxhlet oil (Table 2), which suggests that there were less unsaturated fatty acids in the former than in the latter. The iodine value of the $\mathrm{SC}_{-} \mathrm{CO}_{2}$ oil was also consistent with its higher specific gravity; it was higher than that of the Soxhlet oil (Table 2), indicating that the $\mathrm{SC}-\mathrm{CO}_{2}$ oil contained more unsaturated fatty acids.

Table 2. Yield, physicochemical characteristics and antioxidant activity of Gac seed oil obtained by supercritical (SC)- $\mathrm{CO}_{2}$ and Soxhlet.

\begin{tabular}{|c|c|c|c|c|c|}
\hline \multirow{2}{*}{ Indices } & \multirow{2}{*}{$\begin{array}{c}\text { Method } \\
\text { Standard [9] }\end{array}$} & \multirow{2}{*}{ Unit } & \multicolumn{2}{|c|}{ Mean \pm SD } & \multirow{2}{*}{$\begin{array}{c}\text { Standards for } \\
\text { Vegetable Oil [38] }\end{array}$} \\
\hline & & & $\mathrm{SC}-\mathrm{CO}_{2}$ & Soxhlet * & \\
\hline Yield & & $\%(\mathrm{~m} / \mathrm{m})$ & $34.1 \pm 0.8^{b}$ & $53.0 \pm 2.3^{\mathrm{a}}$ & NA \\
\hline Specific gravity & Cc $10 a-25$ & $25^{\circ} \mathrm{C} /$ water at $20^{\circ} \mathrm{C}$ & $0.895 \pm 0.001^{\mathrm{a}}$ & $0.885 \pm 0.001^{\mathrm{b}}$ & $0.881-0.927$ \\
\hline Refractive index at $40^{\circ} \mathrm{C}$ & Cc $7-25$ & & $1.455 \pm 0.002^{b}$ & $1.462 \pm 0.002^{\mathrm{a}}$ & $1.448-1.477$ \\
\hline Iodine value (Wijs) & Cd 1-25 & $\mathrm{g} \mathrm{I}_{2} / 100 \mathrm{~g}$ oil & $54.15 \pm 0.62^{\mathrm{a}}$ & $51.66 \pm 0.55^{\mathrm{b}}$ & $6-135$, specific to oil \\
\hline Saponification value & Cd 3-35 & $\mathrm{mg} \mathrm{KOH} / \mathrm{g}$ oil & $189.4 \pm 2.1^{\mathrm{a}}$ & $167.2 \pm 4.6^{\mathrm{b}}$ & $168-265$, specific to oil \\
\hline Unsaponifiable matter & Ca $6 a-40$ & $\mathrm{~g} / \mathrm{kg}$ & $33.2 \pm 1.5^{b}$ & $52.6 \pm 2.4^{\mathrm{a}}$ & $\leq 28$ \\
\hline Slip melting point & Cc $3-25$ & ${ }^{\circ} \mathrm{C}$ & $24.8 \pm 0.30^{b}$ & $26.8 \pm 0.65^{\mathrm{a}}$ & NA \\
\hline Free fatty acids & Ca $5-40$ & mg KOH/g oil & $1.74 \pm 0.12^{b}$ & $2.47 \pm 0.09^{\mathrm{a}}$ & $\leq 10$ \\
\hline Peroxide value & $\mathrm{Cd} 8-53$ & meq $\mathrm{O}_{2} / \mathrm{kg}$ oil & $0.12 \pm 0.02^{b}$ & $1.80 \pm 0.01^{\mathrm{a}}$ & $\leq 15$ \\
\hline Moist and volatile matter & Ca 2c-25 & $\%(\mathrm{~m} / \mathrm{m})$ & $0.08 \pm 0.01^{b}$ & $0.12 \pm 0.01^{\mathrm{a}}$ & $\leq 0.2$ \\
\hline Insoluble impurities & Ca 3-46 & $\%(\mathrm{~m} / \mathrm{m})$ & Not detected & $0.04 \pm 0.01$ & $\leq 0.05$ \\
\hline \multicolumn{6}{|l|}{ Antioxidant activity } \\
\hline $\mathrm{DPPH}$ & & $\mu \mathrm{mol} \mathrm{TE} / \mathrm{g}$ oil & $52.69 \pm 0.06^{\mathrm{a}}$ & $42.98 \pm 0.02^{\mathrm{b}}$ & NA \\
\hline ABTS & & $\mu \mathrm{mol} \mathrm{TE} / \mathrm{g}$ oil & $2.10 \pm 0.12^{\mathrm{a}}$ & $1.52 \pm 0.06^{b}$ & NA \\
\hline
\end{tabular}

The mean $\pm \mathrm{SD}$ values for each measurement in the $\mathrm{SC}-\mathrm{CO}_{2}$ and Soxhlet columns not sharing the same superscript letter are significantly different $(p<0.05)$ according to Student's $t$-test, and the letter 'a' denotes a higher value than ‘’. NA: not available; TE: Trolox equivalents.

The range of iodine values measured for the Gac seed oil samples, whether they were extracted with the SC-CO $\mathrm{CO}_{2}$ or the Soxhlet method, was 51.11-54.77 $\mathrm{g} \mathrm{I}_{2} / 100 \mathrm{~g}$ oil. This range was similar to the range of 50.0-55.0 $\mathrm{I}_{2} / 100 \mathrm{~g}$ oil reported for palm oil [38], which suggests that Gac seed oil is very similar to this vegetable oil and, therefore, may have similar applications in the food, cosmetic and biodiesel industries [39-41]. However, the iodine values for the Gac seed oil were low in comparison to other oils, such as canola (188-193), corn (103-128), cottonseed (99-199), linseed (>177), peanut (80-106), rapeseed (94-120), soybean (120-143) and sunflower seed (110-143) oils [36]. The low iodine values for the Gac seed oil were likely due to a high content (60.5\%) of the saturated fatty acid, stearic acid, as measured previously by Ishida et al. [17]. The low iodine values of Gac seed oil place it in the non-drying oil group [32], and being a saturated oil, it is fairly stable to auto-oxidation.

The saponification values obtained for the Gac seed oil samples (Table 2) showed that the value for the $\mathrm{SC}-\mathrm{CO}_{2}$ oil was higher than for the Soxhlet oil. This suggests that the fatty acids in the $\mathrm{SC}-\mathrm{CO}_{2}$ oil were likely to be shorter than those in the Soxhlet oil because the saponification value is an index of the average molecular mass of the fatty acids in an oil sample [42]. This was consistent with the specific gravity of the $\mathrm{SC}-\mathrm{CO}_{2}$ oil being higher than that of the Soxhlet oil, which also suggested that the $\mathrm{SC}-\mathrm{CO}_{2}$ oil contained less long chain fatty acids [31]. 
The range of saponification values for the Gac seed oil samples, whether they were extracted with the SC- $\mathrm{CO}_{2}$ or the Soxhlet method, was $167-189 \mathrm{mg} \mathrm{KOH} / \mathrm{g}$ oil. The range of values was similar to those for mustard seed oil (168-184) [38] and rapeseed oil (168-187) [36]. However, they were lower than for most of the other common oils, such as coconut (248-265), palm (190-209), corn (187-195), cottonseed (189-198), linseed (189-195), peanut (187-196), soybean (189-195) and sunflower seed (188-194) [36]. The low saponification values of the Gac seed oil were likely caused by the high proportion of the C18 long chain fatty acids, stearic (60.5\%), linoleic $(20.3 \%)$ and oleic $(9.0 \%)$, as measured previously by Ishida et al. [17]. However, its low saponification value is an indication that the oil may not be suitable for soap making, for which shorter fatty acids like lauric (C12) and myristic (C14) are preferable [43].

The unsaponifiable matter values obtained for the Gac seed oil samples (Table 2) showed that the value for the $\mathrm{SC}-\mathrm{CO}_{2}$ oil was much lower than for the Soxhlet oil, which is an indication of a higher percentage of oil soluble substances other than triglycerides in the Soxhlet oil. This suggests that the SC- $\mathrm{CO}_{2}$ was not lipophilic enough to extract all the non-polar substances from the Gac seeds that hexane was able to extract. This is consistent with the findings of Friedrich and Pryde [44], who observed that oils extracted from soybeans, cottonseed, corn and wheat germ or bran by SC- $\mathrm{CO}_{2}$ had less impurities, such as unsaponifiables, gossypol and phosphorous, than oils extracted with hexane.

The unsaponifiable matter values for the Gac seed oil (3.3-5.3\%) were very much higher than those for many edible oils, such as soybean oil $(0.015 \%)$, rapeseed oil $(0.02 \%)$, sesame seed oil $(0.02 \%)$ and palm oil $(0.012 \%)$ [45]. More importantly, the unsaponifiable matter values for the Gac seed oil extracts, especially the values for the Soxhlet extracted oil, were higher than the upper limit accepted for edible vegetable oils, which is $28 \mathrm{~g} / \mathrm{kg}$ (2.8\%) [38]. Therefore, the oils as extracted in the current study could not be considered to be edible virgin oils and would need to be refined as for most crude seed oils [46].

Gac seed oil is known to contain triterpenoids, steroids and tocopherols, which can be part of the unsaponifiable matter of oils [47]. These compounds do not contain glyceride linkages, and thus, they are unable to be hydrolysed during saponification [48]. Kan et al. [49] have reported the presence of seven triterpenoids in the unsaponifiable matter of Gac seed oil: karounidiol, isokarounidiol, 5-dehydrokarounidiol, 7-oxodihydrokarounidiol, beta-sitosterol, stigmast-7-en-3beta-ol and stigmast-7, 22-dien-3beta-ol. Therefore, it is likely that the unsaponifiable substances in the Gac oil extracted in the present study were due to these triterpenoid saponins [50-52]. For example, Le et al. [52] found that a considerable proportion $(\approx 75 \%)$ of the Gac seed saponins was deposited in its oil body. Tocopherols, which have been found in Gac seed oil at a concentration of $274 \mathrm{mg} / 100 \mathrm{~g}$ oil [7], may also have contributed to the unsaponifiable matter.

Although the present Gac seed oil samples would not be acceptable for food applications in terms of their high unsaponifiable matter, they may still be useful in terms of medicinal applications. Their high unsaponifiable matter content may be advantageous as there have been reports on potential beneficial medicinal properties of Gac seed triterpenoids due to their anti-inflammatory [53], anticancer [54] and tumour-inhibitory [55] activities. In this context, the Gac seed oil extracted using the Soxhlet method may be more advantageous than the $\mathrm{SC}-\mathrm{CO}_{2}$ oil because the unsaponifiable matter for the Soxhlet oil was $58 \%$ higher than for the $\mathrm{SC}-\mathrm{CO}_{2}$ oil.

The slip melting point of the SC- $\mathrm{CO}_{2}$ oil was significantly lower than that of the Soxhlet oil (Table 2), again confirming that the $\mathrm{SC}-\mathrm{CO}_{2}$ was less able to extract saturated or long chain lipids [31]. This was consistent with the iodine values, a measure of unsaturation, which were higher for the SC- $\mathrm{CO}_{2}$ oil than for the Soxhlet oil (Table 2). Compared to other oils, the slip point values for the Gac seed oils $\left(24.5-27.5^{\circ} \mathrm{C}\right)$ were similar to those of coconut $\left(23-26^{\circ} \mathrm{C}\right)$, babassu $\left(24-26^{\circ} \mathrm{C}\right)$ and palm kernel $\left(23-30{ }^{\circ} \mathrm{C}\right)$ oils [56] but lower than for palm oil $\left(31.1-37.6^{\circ} \mathrm{C}\right)$. The melting point of an oil defines its hardness and thermal behaviour and is directly affected by the structure of its fatty acids in that 
unsaturated fatty acids give an oil a lower slip melting point than saturated fatty acids and short chain fatty acids give lower values than long chain fatty acids [31].

The free fatty acid values for the SC-CO $\mathrm{CO}_{2}$ oil were lower than for the Soxhlet oil (Table 2), and this may simply be due to the difference in the length of the two extractions. Although the temperatures used for the two methods were similar, $73{ }^{\circ} \mathrm{C}$ for the $\mathrm{SC}-\mathrm{CO}_{2}$ extraction and $68{ }^{\circ} \mathrm{C}$ for the Soxhlet extraction, the extraction time for the Soxhlet extraction $(8 \mathrm{~h})$ was much longer than for the $\mathrm{SC}-\mathrm{CO}_{2}$ extraction $(\approx 10 \mathrm{~min})$. Therefore, the possibility that the fatty acids were hydrolysed from triglycerides during the extraction process was higher for the Soxhlet oil than for the $\mathrm{SC}-\mathrm{CO}_{2}$ oil.

The free fatty acid values for both Gac seed oils varied from 1.47-2.47, indicating that the range for the free fatty acid content was higher than for edible oils like soybean oil $(0.38-0.54)$ and palm oil (0.17-1.06), but lower than for mustard oil (3.65-4.5) [57]. The presence of free fatty acids in an oil can promote auto-oxidation reactions, and they should be as low as possible. However, the acceptable limit for free fatty acids is $10 \mathrm{mg} \mathrm{KOH} / \mathrm{g}$ oil [38], and therefore, the values for the Gac seed oils were far below this limit.

The primary oxidation products of fatty acids are usually peroxides, which are measured by the peroxide value [35]. The peroxide value for the $\mathrm{SC}-\mathrm{CO}_{2}$ oil was $93 \%$ lower than for the Soxhlet oil (Table 2). As for the free fatty acid values, the lower peroxide value for the $\mathrm{SC}-\mathrm{CO}_{2}$ oil than for the Soxhlet oil may simply be due to the difference in the length of the two extractions; the extraction time for the Soxhlet extraction $(8 \mathrm{~h})$ was much longer than for the $\mathrm{SC}-\mathrm{CO}_{2}$ extraction $(\approx 10 \mathrm{~min})$, and therefore, there was more time for the fatty acids to be oxidised during the Soxhlet extraction than during the $\mathrm{SC}-\mathrm{CO}_{2}$ extraction. Furthermore, because the $\mathrm{SC}-\mathrm{CO}_{2}$ apparatus is sealed from the atmosphere, exposure to oxygen is avoided during the short $\mathrm{SC}-\mathrm{CO}_{2}$ extraction.

Compared to the acceptable limit of $15 \mathrm{meq}_{2} / \mathrm{kg}$ oil [38], the peroxide values for the Gac seed oils were both well below this threshold, and therefore, the oils were very stable and not susceptible to oxidation. This is consistent with the low iodine values observed for the Gac seed oils (Table 2) and their high content of saturated fatty acids (60.5\% stearic), as measured previously [17]. The presence of tocopherols in Gac seed oil [7] may also contribute to the oil's resistance to the lipid oxidation processes [58].

The moist and volatile matter value for the SC- $\mathrm{CO}_{2}$ oil was lower than for the Soxhlet oil (Table 2), but the values for both Gac seed oils were lower than the acceptable standard level $(0.2 \%)$ for vegetable oils [38]. The higher value of the Soxhlet oil, compared to the SC- $\mathrm{CO}_{2}$ oil, was consistent with this oil also having the higher free fatty acids value (Table 2); the observed higher free fatty acids value was likely the consequence of an increased hydrolysis of fatty acids from the triglycerides in the presence of a higher moisture content in the Soxhlet oil.

In terms of insoluble impurities, the Gac seed oil extracted by $\mathrm{SC}-\mathrm{CO}_{2}$ had no detectable impurities, while the values for the Soxhlet oil were measurable (Table 2). This insoluble impurities value is a measure of unwanted materials suspended in the oil, such as oxidized fatty acids and alkaline soaps of palmitic and stearic acids, among other materials [38]. Therefore, the observed higher insoluble impurities were consistent with both the higher peroxide value (e.g., oxidised fatty acids) and the higher free fatty acid values (e.g., stearic acid) for the Soxhlet oil compared to the $\mathrm{SC}-\mathrm{CO}_{2}$ oil (Table 2). Nonetheless, the level of insoluble impurities in the Soxhlet oil was still below the acceptable threshold of $0.05 \%$ for edible oils [38].

The oil extracted by SC- $\mathrm{CO}_{2}$ had a higher antioxidant capacity than the Soxhlet oil for both of the antioxidant assays performed (Table 2). This may be because of the shorter extraction time needed for the SC- $\mathrm{CO}_{2}$ extraction $(\approx 10 \mathrm{~min})$ than for the Soxhlet extraction $(8 \mathrm{~h})$, and therefore, the former may have more heat-sensitive antioxidant compounds, such as tocopherols, saponins and phenolics, remaining than the latter.

The values for the DPPH assay were much higher ( $>25$ times) than for the ABTS assays for both of the extracted Gac seed oils (Table 2). The antioxidant activity values for the Gac seed oils (DPPH: 1076-1319 and ABTS: 38-53 mg trolox/100 g oil) were also much higher for the DPPH assay, 
but similar for the ABTS assay when compared to the DPPH and ABTS antioxidant activity values reported for some seed oils, such as hemp (62 and $40 \mathrm{mg}$ trolox/100 g oil, respectively), terebinth (52 and $47 \mathrm{mg}$ trolox/100 g oil, respectively), radish (53 and $36 \mathrm{mg}$ trolox/100 g oil, respectively), stinging nettle (46 and $33 \mathrm{mg}$ trolox/100 g oil, respectively) and laurel ( 86 and $85 \mathrm{mg}$ trolox/100 g oil, respectively) [59].

The very high DPPH antioxidant activity measured for the Gac seed oils in this study are likely due to the modifications used for this assay in the present study and, therefore, may not be able to be compared with other studies. The main modification was that ethyl acetate was used as the solvent for the DPPH and the oil samples instead of methanol [15], and therefore, it suggests that ethyl acetate may be better than methanol at solubilising the antioxidant compounds in the Gac seed oils. For the ABTS assay, the oil samples were dissolved in dichloromethane, and the ABTS was dissolved in methanol instead of 1-butanol and water, respectively [16], but the values were similar to those obtained for other oils [59].

In summary, the SC-CO $\mathrm{CO}_{2}$ oil appeared to have a higher quality than the Soxhlet oil in terms of free fatty acids, peroxide value, insoluble impurities, moist and volatile matter and antioxidant activity (Table 2). However, both oils, as extracted in this study, could not be used as edible virgin oil because of their high unsaponifiable matter [38], but for the same reason, they may have more potential in medicinal applications. In this context, the Soxhlet oil may have more potential because it had a higher unsaponifiable matter value and a much higher yield than the $\mathrm{SC}-\mathrm{CO}_{2}$ oil.

\subsection{Colour Characterisation}

As seen in Table 3, the SC- $\mathrm{CO}_{2}$ oil had a light yellow colour, and therefore, it had a much better colour than the Soxhlet oil, which had a much darker colour and would not require bleaching during the refining process. The CIELab colour measurements reflected this colour difference as significant differences $(p<0.05)$ were found for the $L^{*}, a^{*}$ and $b^{*}$ values between the two oils (Table 3); a higher value for $\mathrm{L}^{*}$, reflecting more brightness, a lower and negative value for $\mathrm{a}^{*}$, reflecting more green than red, and a higher value for $\mathrm{b}^{*}$, reflecting more yellow than blue, were found for the $\mathrm{SC}-\mathrm{CO}_{2}$ oil than for the Soxhlet oil (Table 3). According to Kraujalyte et al. [60], the colour of a vegetable oil depends mainly on the presence of carotenoids and chlorophylls in the oil. Therefore, the darker colour of the Gac seed oil extracted with hexane is probably due to this solvent's capacity to extract carotenoids and chlorophylls [61-63] compared to the more polar solvent carbon dioxide. This is also consistent with the Soxhlet oil having a higher unsaponifiable matter than the SC- $\mathrm{CO}_{2}$ oil (Table 2), part of which could be carotenoids and chlorophyll. However, based on the bright green colour of the Soxhlet extract observed before the hexane was evaporated, chlorophyll is likely to be a major pigment in this oil.

Table 3. Colour (CIELab) of Gac seed oils extracted by SC-CO $\mathrm{CO}_{2}$ and Soxhlet.

\begin{tabular}{|c|c|c|c|c|}
\hline \multirow{2}{*}{$\begin{array}{l}\text { Extraction } \\
\text { Method }\end{array}$} & \multirow{2}{*}{ Colour } & \multicolumn{3}{|c|}{ Colour Measurements } \\
\hline & & $L^{*}$ & $a^{*}$ & $\mathbf{b}^{*}$ \\
\hline $\mathrm{SC}-\mathrm{CO}_{2}$ & Light yellow & $62.65 \pm 7.14^{a}$ & $-1.73 \pm 0.23^{a}$ & $47.32 \pm 2.38^{a}$ \\
\hline Soxhlet & $\begin{array}{l}\text { Dark greenish } \\
\text { brown }\end{array}$ & $27.12 \pm 5.59^{b}$ & $11.46 \pm 0.29^{b}$ & $5.88 \pm 0.86^{b}$ \\
\hline
\end{tabular}

The mean \pm SD values for each measurement not sharing a superscript letter indicate significant $(p<0.002)$ differences according to Student's $t$-test. 
There are currently no colour standards for Gac seed oil, and the $L^{*} a^{*} b^{*}$ measurements could be useful for developing a colour classification system.

\section{Conclusions}

Compared to other oilseeds, Gac seed kernel was found to possess a very high oil content. However, when extracted, the oil could not be considered an edible virgin oil due to its high percentage of unsaponifiable matter. The oil yield was higher with the Soxhlet extraction using hexane than with the SC- $\mathrm{CO}_{2}$ apparatus, but the Soxhlet oil had a considerably higher unsaponifiable matter content than the SC- $\mathrm{CO}_{2}$ oil. The Gac seed oil extracted by $\mathrm{SC}-\mathrm{CO}_{2}$ had better oil qualities, including antioxidant capacity, colour, peroxide value, free fatty acid value and unsaponifiable matter than the Soxhlet oil. Therefore, although further refining of both extracted Gac seed oils would be needed to achieve the safety criteria prescribed for edible oils, the $\mathrm{SC}-\mathrm{CO}_{2}$ would require less effort to bring it within the criteria.

Some of the unsaponifiable matter in the oil may make it useful for medicinal purposes. In this context, the Soxhlet oil may have more potential than the $\mathrm{SC}-\mathrm{CO}_{2}$ oil due to its higher unsaponifiable matter content. However, further composition analysis of the unsaponifiable matter and studies on the biological activities of the hexane-extracted Gac seed oil are needed to confirm the feasibility of using this oil as a medicinal ingredient.

Author Contributions: Conceptualization, A.V.L., M.H.N. and P.D.R. Methodology, A.V.L. Validation, A.V.L. Formal analysis, A.V.L. Investigation, A.V.L. Data curation, A.V.L. and P.D.R. Writing, original draft preparation, A.V.L. Writing, review and editing, P.D.R., M.H.N. and S.E.P. Supervision, P.D.R., M.H.N. and S.E.P.

Funding: This research received no external funding.

Acknowledgments: A.V.L. acknowledges the University of Newcastle and the Vietnamese Ministry of Education and Training (MOET) for their financial support.

Conflicts of Interest: The authors declare no conflict of interest.

\section{References}

1. Tran, X.T.; Parks, S.E.; Roach, P.D.; Golding, J.B.; Nguyen, M.H. Effects of maturity on physicochemical properties of Gac fruit (Momordica cochinchinensis Spreng.). Food Sci. Nutr. 2016, 4, 305-314. [CrossRef] [PubMed]

2. Kha, T.C.; Nguyen, M.H.; Roach, P.D.; Parks, S.E.; Stathopoulos, C. Gac fruit: Nutrient and phytochemical composition, and options for processing. Food Rev. Int. 2013, 29, 92-106. [CrossRef]

3. Chuyen, H.V.; Nguyen, M.H.; Roach, P.D.; Golding, J.B.; Parks, S.E. Gac fruit (Momordica cochinchinensis Spreng): A rich source of bioactive compounds and its potential health benefits. Int. J. Food Sci. Technol. 2015, 50, 567-577. [CrossRef]

4. Masayo, I.; Hikaru, O.; Tatsuo, Y.; Masako, T.; Yoshie, R.; Shuji, H.; Mihashi, K.; Higuchi, R. Studies on the constituents of Momordica cochinchinensis Spreng. I. Isolation and characterization of the seed saponins, Momordica saponins I and II. Chem. Pharm. Bull. 1985, 33, 464-478. [CrossRef]

5. Behera, T.; John, K.J.; Bharathi, L.; Karuppaiyan, R. Wild Crop Relatives: Genomic and Breeding Resources: Vegetables. In Wild Crop Relatives: Genomic and Breeding Resources; Kole, C., Ed.; Springer: New York, NY, USA, 2011; pp. 217-246.

6. Shang, H. Studies on Fatty Acid Composition in the Oil of Momordica cochinchinensis. Chin. Tradit. Herbal Drugs 2000, 31, 727-728.

7. Matthaus, B.; Vosmann, K.; Pham, L.Q.; Aitzetmüller, K. FA and tocopherol composition of Vietnamese oilseeds. J. Am. Oil Chem. Soc. 2003, 80, 1013-1020. [CrossRef]

8. Q3C-Tables and List Guidance for Industry. Available online: https://www.fda.gov/downloads/drugs / guidances/ucm073395.pdf (accessed on 10 October 2012).

9. Stahl, E.; Schuetz, E.; Mangold, H.K. Extraction of seed oils with liquid and supercritical carbon dioxide. J. Agric. Food Chem. 1980, 28, 1153-1157. [CrossRef] 
10. Venturi, F.; Sanmartin, C.; Taglieri, I.; Andrich, G.; Zinnai, A. A simplified method to estimate $\mathrm{Sc}-\mathrm{CO}_{2}$ extraction of bioactive compounds from different matrices: Chili pepper vs. tomato by-products. Appl. Sci. 2017, 7, 361. [CrossRef]

11. Anh, V.L.; Paul, D.R.; Minh, H.N.; Sophie, E.P. Optimisation of process parameters for supercritical carbon dioxide extraction of oil from Gac seed kernel powder. Adv. J. Food Sci. Technol. 2017, 13, 170-177. [CrossRef]

12. Firestone, D. Official Methods and Recommended Practices of the American Oil Chemists Society, 5th ed.; AOCS Press: Champaign, IL, USA, 1998; ISBN 0935315977.

13. Da Porto, C.; Porretto, E.; Decorti, D. Comparison of ultrasound-assisted extraction with conventional extraction methods of oil and polyphenols from grape (Vitis vinifera L.) seeds. Ultrason. Sonochem. 2013, 20, 1076-1080. [CrossRef] [PubMed]

14. Xu, X.Q. A chromametric method for the rapid assessment of deep frying oil quality. J. Sci. Food Agric. 2003, 83, 1293-1296. [CrossRef]

15. Tan, S.P.; Stathopoulos, C.; Parks, S.; Roach, P. An optimised aqueous extract of phenolic compounds from bitter melon with high antioxidant capacity. Antioxidants 2014, 3, 814-829. [CrossRef] [PubMed]

16. Christodouleas, D.C.; Fotakis, C.; Nikokavoura, A.; Papadopoulos, K.; Calokerinos, A.C. Modified DPPH and ABTS assays to assess the antioxidant profile of untreated oils. Food Anal. Methods 2015, 8, 1294-1302. [CrossRef]

17. Ishida, B.K.; Turner, C.; Chapman, M.H.; McKeon, T.A. Fatty acid and carotenoid composition of Gac (Momordica cochinchinensis Spreng) fruit. J. Agric. Food Chem. 2004, 52, 274-279. [CrossRef] [PubMed]

18. Ezeagu, I.; Maziya-Dixon, B.; Tarawali, G. Seed characteristics and nutrient and antinutrient composition of 12 Mucuna accessions from Nigeria. Trop. Subtrop. Agroecosyst. 2003, 1, 129-139.

19. Gupta, R.; Das, S. Fracture resistance of sunflower seed and kernel to compressive loading. J. Food Eng. 2000, 46, 1-8. [CrossRef]

20. Applewhite, T.H. Proceedings of the World Conference on Oilseed Technology And Utilization; The American Oil Chemists Society: Urbana, IL, USA, 1993; ISBN 0935315454.

21. Saiedirad, M.; Tabatabaeefar, A.; Borghei, A.; Mirsalehi, M.; Badii, F.; Varnamkhasti, M.G. Effects of moisture content, seed size, loading rate and seed orientation on force and energy required for fracturing cumin seed (Cuminum cyminum Linn.) under quasi-static loading. J. Food Eng. 2008, 86, 565-572. [CrossRef]

22. Brooker, D.B.; Bakker-Arkema, F.W.; Hall, C.W. Drying and Storage of Grains and Oilseeds; Springer Science and Business Media: Berlin/Heidelberg, Germany, 1992; ISBN 0442205155.

23. Olaofe, O.; Adeyemi, F.; Adediran, G.O. Amino acid and mineral compositions and functional properties of some oilseeds. J. Agric. Food Chem. 1994, 42, 878-881. [CrossRef]

24. Frandsen, G.I.; Mundy, J.; Tzen, J.T. Oil bodies and their associated proteins, oleosin and caleosin. Physiol. Plant 2001, 112, 301-307. [CrossRef] [PubMed]

25. Stahl, E.; Quirin, K.W.; Blagrove, R.J. Extraction of seed oils with supercritical carbon dioxide: Effect on residual proteins. J. Agric. Food Chem. 1984, 32, 938-940. [CrossRef]

26. Wong, R.C.; Fong, W.; Ng, T. Multiple trypsin inhibitors from Momordica cochinchinensis seeds, the Chinese drug mubiezhi. Peptides 2004, 25, 163-169. [CrossRef] [PubMed]

27. Makkar, H.; Becker, K.; Schmook, B. Edible provenances of Jatropha curcas from Quintana Roo state of Mexico and effect of roasting on antinutrient and toxic factors in seeds. Plant Foods Hum. Nutr. 1998, 52, 31-36. [CrossRef] [PubMed]

28. Raheja, R.; Batta, S.; Ahuja, K.; Labana, K.; Singh, M. Comparison of oil content and fatty acid composition of peanut genotypes differing in growth habit. Plant Foods Hum. Nutr. 1987, 37, 103-108. [CrossRef]

29. Zheljazkov, V.D.; Vick, B.A.; Ebelhar, M.W.; Buehring, N.; Baldwin, B.S.; Astatkie, T.; Miller, J.F. Yield, oil content, and composition of sunflower grown at multiple locations in Mississippi. Agron. J. 2008, 100, 635-642. [CrossRef]

30. Were, B.A.; Onkware, A.O.; Gudu, S.; Welander, M.; Carlsson, A.S. Seed oil content and fatty acid composition in East African sesame (Sesamum indicum L.) accessions evaluated over 3 years. Field Crops. Res. 2006, 97, 254-260. [CrossRef]

31. Gunstone, F. The Chemistry of Oils and Fats: Sources, Composition, Properties and Uses; John Wiley \& Sons: Hoboken, NJ, USA, 2009; ISBN 1405150025.

32. Zhao, G.; Ren, Y.; Ma, H. Extraction and characterization of radish seed oils using different methods. Trop. J. Pharm. Res. 2017, 16, 165-169. [CrossRef] 
33. Gómez, A.M.; López, C.P.; de la Ossa, E.M. Recovery of grape seed oil by liquid and supercritical carbon dioxide extraction: A comparison with conventional solvent extraction. Chem. Eng. J. Biochem. Eng. J. 1996, 61, 227-231. [CrossRef]

34. Noureddini, H.; Teoh, B.; Clements, L.D. Densities of vegetable oils and fatty acids. J. Am. Oil Chem. Soc. 1992, 69, 1184-1188. [CrossRef]

35. Gunstone, F.D. Rapeseed and Canola Oil: Production, Processing, Properties and Uses; CRC Press: Boca Raton, FL, USA, 2004; ISBN 0849323649.

36. Knothe, G. Structure indices in FA chemistry. How relevant is the iodine value? J. Am. Oil Chem. Soc. 2002, 79, 847-854. [CrossRef]

37. Kyriakidis, N.B.; Katsiloulis, T. Calculation of iodine value from measurements of fatty acid methyl esters of some oils: Comparison with the relevant American oil chemists society method. J. Am. Oil Chem. Soc. 2000, 77, 1235-1238. [CrossRef]

38. Codex, A.C. Codex Alimentarius: Fats, Oils and Related Products; Food and Agriculture Organisation: Quebec, QC, Canada, 2001; ISBN 9251046824.

39. Koh, L.P.; Wilcove, D.S. Cashing in palm oil for conservation. Nature 2007, 448, 993. [CrossRef] [PubMed]

40. Mekhilef, S.; Siga, S.; Saidur, R. A review on palm oil biodiesel as a source of renewable fuel. Renew. Sust. Energy Rev. 2011, 15, 1937-1949. [CrossRef]

41. Mba, O.I.; Dumont, M.-J.; Ngadi, M. Palm oil: Processing, characterization and utilization in the food industry-A review. Food Biosci. 2015, 10, 26-41. [CrossRef]

42. Patterson, H.B.W. Quality and Control. In Hydrogenation of Fats and Oils: Theory and Practice, 2nd ed.; List, G.R., King, J.W., Eds.; Elsevier Inc.: Urbana, IL, USA, 2011; pp. 329-350.

43. Kumar, A.; Sharma, S. An evaluation of multipurpose oil seed crop for industrial uses (Jatropha curcas L.): A review. Ind. Crops. Prod. 2008, 28, 1-10. [CrossRef]

44. Friedrich, J.; Pryde, E. Supercritical $\mathrm{CO}_{2}$ extraction of lipid-bearing materials and characterization of the products. J. Am. Oil Chem. Soc. 1984, 61, 223-228. [CrossRef]

45. Paul, B.; Munshi, M.; Ahmed, M.; Saha, G.; Roy, S. The fatty acid composition and properties of oil extracted from fresh rhizomes of turmeric (Curcuma longa Linn.) cultivars of Bangladesh. Bangladesh J. Sci. Ind. Res. 2011, 46, 127-132. [CrossRef]

46. Hamm, W.; Hamilton, R.J.; Calliauw, G. Edible Oil Processing; John Wiley \& Sons: Hoboken, NJ, USA, 2013; ISBN 1118541782.

47. Fontanel, D. Unsaponifiable Matter in Plant Seed Oils; Springer: New York, NY, USA, 2013; ISBN 3642357091.

48. Bailey, A.E. Industrial Oil and Fat Products; Interscience Publishers, Inc.: New York, NY, USA, 1945; ISBN 9780471678496.

49. Kan, L.; Hu, Q.; Chao, Z.; Song, X.; Cao, X. Chemical constituents of unsaponifiable matter from seed oil of Momordica cochinchinensis. China J. Chin. Mater. Med. 2006, 31, 1441-1444.

50. Shan, M.D.; Hu, L.H.; Chen, Z.L. A new multiflorane triterpenoid ester from Momordica cochinchinensis Spreng. Nat. Prod. Lett. 2001, 15, 139-145. [CrossRef] [PubMed]

51. Lin, Z.Y.; Liu, X.; Yang, F.; Yu, Y.Q. Structural characterization and identification of five triterpenoid saponins isolated from Momordica cochinchinensis extracts by liquid chromatography/tandem mass spectrometry. Int. J. Mass Spectrom. 2012, 328, 43-66. [CrossRef]

52. Le, A.V.; Parks, S.E.; Nguyen, M.H.; Roach, P.D. Optimisation of the microwave-assisted ethanol extraction of saponins from Gac (Momordica cochinchinensis Spreng) seeds. Medicines 2018, 5, 70. [CrossRef] [PubMed]

53. Jung, K.; Chin, Y.-W.; Yoon, K.D.; Chae, H.-S.; Kim, C.Y.; Yoo, H.; Kim, J. Anti-inflammatory properties of a triterpenoidal glycoside from Momordica cochinchinensis in LPS-stimulated macrophages. Immunopharmacol. Immunotoxicol. 2013, 35, 8-14. [CrossRef] [PubMed]

54. Akihisa, T.; Tokuda, H.; Ichiishi, E.; Mukainaka, T.; Toriumi, M.; Ukiya, M.; Yasukawa, K.; Nishino, H. Anti-tumor promoting effects of multiflorane-type triterpenoids and cytotoxic activity of karounidiol against human cancer cell lines. Cancer Lett. 2001, 173, 9-14. [CrossRef]

55. Yasukawa, K.; Akihisa, T.; Tamura, T.; Takido, M. Inhibitory effect of karounidiol on 12-O-tetradecanoylphorbol-13-acetate-induced tumor promotion. Biol. Pharm. Bull. 1994, 17, 460-462. [CrossRef] [PubMed]

56. Firestone, D. Physical and Chemical Characteristics of Oils, Fats, and Waxes; AOCS press: Urbana, IL, USA, 2013; ISBN 0983079196. 
57. Mowlah, G.; Sheikh, N.M.; Kamal, A.S.M. A Hand Book on Edible Oils and Fats, with Special Reference to Bangladesh, 1st ed.; University of Dhaka: Dhaka, Bangladesh, 1990; pp. 9-172.

58. Kamal-Eldin, A.; Appelqvist, L.Å. The chemistry and antioxidant properties of tocopherols and tocotrienols. Lipids 1996, 31, 671-701. [CrossRef] [PubMed]

59. Uluata, S.; Özdemir, N. Antioxidant activities and oxidative stabilities of some unconventional oilseeds. J. Am. Oil Chem. Soc. 2012, 89, 551-559. [CrossRef] [PubMed]

60. Kraujalyte, V.; Andjelkovic, M.; Verhé, R.; Venskutonis, P.R. Determination of volatiles, tocopherols and colour changes in aromatised oils with marjoram. FOODBALT-2011 2011, 2011, 84. [CrossRef]

61. Vernon, L.P.; Seely, G.R. The Chlorophylls; Academic Press: Cambridge, MA, USA, 2014; ISBN 1483267725.

62. Boutaoui, N.; Zaiter, L.; Benayache, F.; Benayache, S.; Carradori, S.; Cesa, S.; Giusti, A.M.; Campestre, C.; Menghini, L.; Innosa, D.; et al. Qualitative and quantitative phytochemical analysis of different extracts from Thymus algeriensis aerial parts. Molecules 2018, 23, 463. [CrossRef] [PubMed]

63. Boutaoui, N.; Zaiter, L.; Benayache, F.; Benayache, S.; Cacciagrano, F.; Cesa, S.; Secci, D.; Carradori, S.; Giusti, A.M.; Campestre, C.; et al. Atriplex mollis Desf. aerial parts: Extraction procedures, secondary metabolites and color analysis. Molecules 2018, 23, 1962. [CrossRef] [PubMed]

(C) 2018 by the authors. Licensee MDPI, Basel, Switzerland. This article is an open access article distributed under the terms and conditions of the Creative Commons Attribution (CC BY) license (http:/ / creativecommons.org/licenses/by/4.0/). 